\title{
Competitiveness and Determinants of Bank Profitability in Sub-Saharan Africa
}

\author{
Isaiah Oino $^{1}$ \\ ${ }^{1}$ School of Business and Law, University of East London, UK \\ Correspondence: Isaiah Oino, School of Business and Law, University of East London, UK. E-mail: \\ i.oino@uel.ac.uk
}

Received: July 16, 2015

Accepted: September 6, $2015 \quad$ Online Published: September 25, 2015

doi:10.5539/ijef.v7n10p151

URL: http://dx.doi.org/10.5539/ijef.v7n10p151

\begin{abstract}
We analyse how competitive the banks in sub-Saharan Africa are and what determines their profitability. We use a panel data of 97 sub-Saharan African banks for the period from 2000 to 2012. Using recursive regression, there is no strong evidence to suggest a structural break. The findings indicate that on average banks have a $40 \%$ return on equity. The fixed effects indicate that both internal and external factors are influential in determining the profitability of the banks. Specifically, the cost-income ratio and capital ratio negatively and significantly influence profitability. Measuring revenue diversification with the Herfindahl-Hirschman index (HHI), the results indicate that the more diversified the bank is, the more profitable it is. On the other hand, we find that the coefficient of cyclical output almost doubles when the output exceeds its trend value. In contrast, when the output is below its trend, the coefficient of cyclical output is insignificant.
\end{abstract}

Keywords: sub-sahara, banks, efficiency, profitability

\section{Introduction}

The economic growth of a region or country has been attributed to the financial development in terms of the stock market, bond market and derivative market. This is because institutions like banks assess the creditworthiness of the borrower and the viability of the investment to ensure efficient allocation of resources. Moreover, in order for promising projects to be exploited, banks and securities markets mobilize households to save in order to lend and monitor the investments and the performance of the managers. Africa is one of the continents that is endowed with vast resources and yet lags behind on economic fronts. This is despite the fact that banks in Africa are the most profitable financial institutions in the world but have a modest global rating (Valentina et al., 2009). The profitability could be attributed to the standard asset pricing model, which implies that risk assets are remunerated with higher returns. Therefore, the profitability of the bank should indicate specific risks as well as risks associated with the macroeconomic environment. As a result of the 2007 global financial crisis, financial institutions have undergone tremendous reforms. However, such reforms, which among others encompass minimum regulatory capital requirements, bonus payments and identification of risks, are in tandem with the legal framework. Other recent reforms that have enhanced financial liberalization include interest rate controls, particularly in Kenya, Tanzania and Ghana.

The financial liberation has led to the growth of banks across Africa, predominately for private banks and the entry of foreign banks. Attempts have been made to enhance financial stability, for instance recapitalization, which resulted in a reduction in the number of banks (Note 1). A basic comparison of data between developing and developed countries shows that financial systems in developing economies tend to be less efficient. For instance, the average depth of financial institutions (measured as private credit to gross domestic product (GDP)) and markets (measured as stock market capitalization plus outstanding domestic private debt securities to GDP) in developed economies is more than twice that in developing economies. However, in terms of the stability of financial institutions (measured by the Z-score), on average, the banking systems in developing economies are less volatile than those in developed economies (World Bank Financial Database, 2013). The levels of stability of financial markets (measured as the asset price volatility) are similar, on average, for developed and developing economies. Therefore, the objective of this research is not only to examine how competitive the banks in sub-Saharan Africa (SSA) are but also assess the internal and external factors that influence profitability.

The remainder of this paper is organized as follows. Section two briefly discusses the theoretical and empirical 
results of related banking studies, section 3 identifies the variables of interest, section 4 is on economic modelling, section 5 presents empirical results, and section 6 concludes.

\section{Literature Review}

A number of studies have explored the possible reasons for the poor performance of banks in Africa. Chief among the reasons is the high degree of financial market fragmentation and limited access to basic payment services (Nissanke \& Aryeetey, 1998). For instance, the financial access to banking services in Africa is much lower compared with that in developed countries, as shown below.

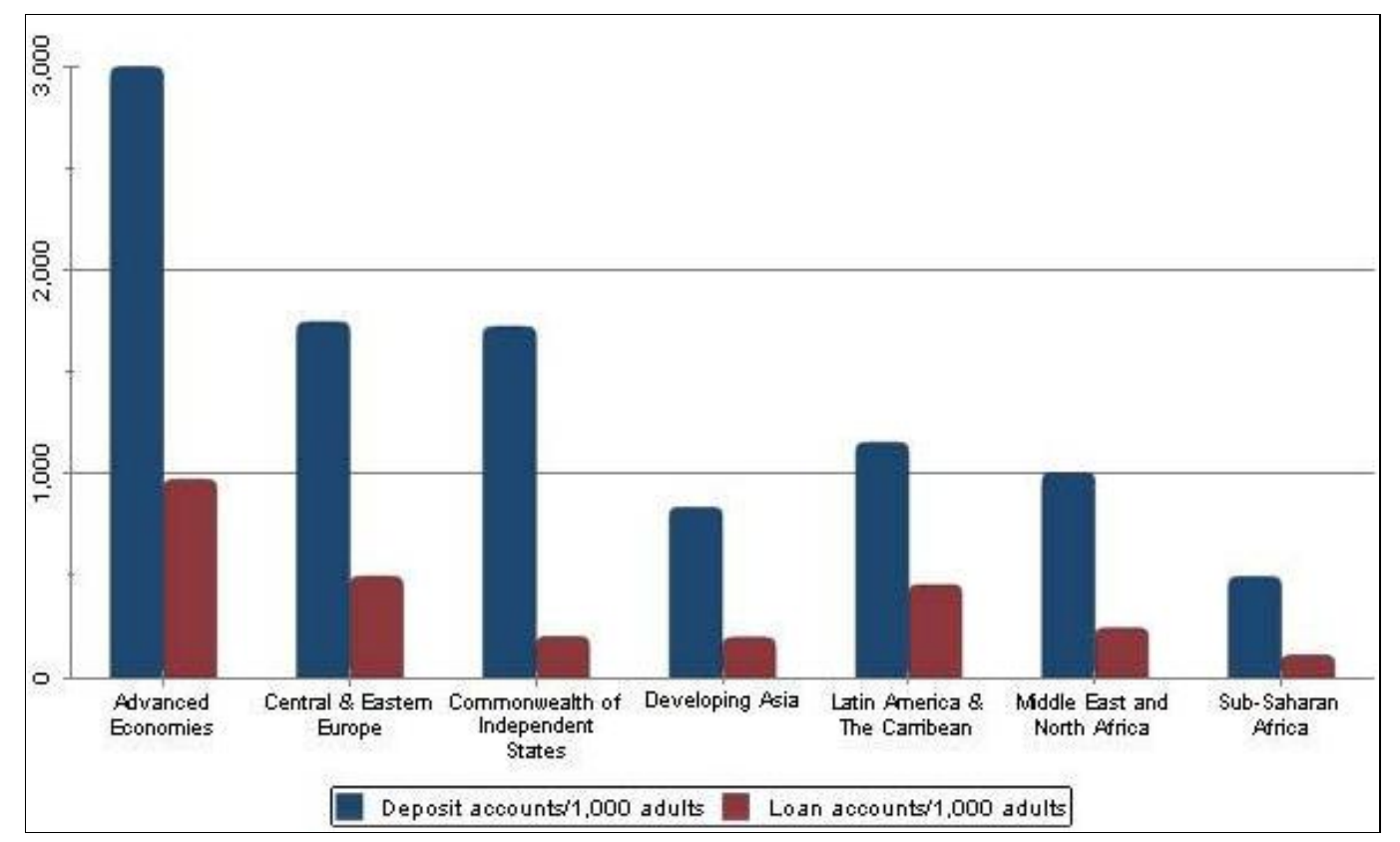

Figure 1. The number of accounts in commercial banks, regional means (2011)

Source: Financial Access Survey (FAS) countries grouped according to the World Economic Outlook regions.

Using cointegration and an error correction model, Chirwa (2003) tested the collusion hypothesis and whether there is a relationship between profit and concentration of the banking industry in Malawi, using time series data between 1970 and 1994. The collusion hypothesis proposes that market concentration lowers the cost of collusion between firms and results in higher than normal profits. On the other hand, the efficient structure hypothesis postulates that the most efficient firms obtain greater profitability and market share and, as a consequence, the market becomes more concentrated. The results obtained from the study support the traditional collusion hypothesis of a long-run positive relationship between concentration and performance. The dynamic short-run analysis also shows a high speed of adjustment in profitability from disequilibrium and indicates a positive response in profitability to a negative deviation from a long-run equilibrium.

Panayiotis et al. (2006) examined the profitability behaviour of bank-specific, industry-related and macroeconomic determinants, using an unbalanced panel data set of South Eastern European (SEE) credit institutions over the period 1998-2002. The results showed that bank profitability is a function of internal and external factors. The internal factors include bank-specific factors, while the external factors include both industry-specific and macroeconomic factors.

\subsection{Size}

A whole new structural effects trend on bank profitability started with the application of the market-power (MP) and efficient-structure (ES) hypotheses. The MP hypothesis, which is sometimes also referred to as the structureconduct-performance (SCP) hypothesis, asserts that increased market power yields monopoly profits. A special case of the MP hypothesis is the relative-market-power (RMP) hypothesis, which suggests that only firms with large market shares and well-differentiated products are able to exercise market power and earn non-competitive profits (Berger, 1995). In addition, the size of the bank is introduced to account for the existing economies or 
diseconomies of scale in the market. Therefore, larger banks are likely to have a higher degree of product and loan diversification than smaller banks.

The impact of a bank's size on its profitability is not uniform. In a study of European banks for the period of 1992 to 1998, Goddard et al. (2004) identified only a slight relationship between size and profitability. Some earlier studies attained different results. Smirlock (1985) proved a significant and positive impact of a bank's size on its profitability. Short (1979) claimed that size has a positive influence on profitability through lowering the cost of raising capital for big banks. Later, studies by Bikker and Hu (2002) and Goddard et al. (2004) supported the proposition that increasing a bank's size positively affects its profitability through the cost of capital. However, there is no consensus in the literature on whether an increase in size provides banks with economies of scale. For example, some research, including that by Berger et al. (1987), claimed that there is no significant relationship between profitability and size. Likewise, Micco et al. (2007) noted that there is no correlation between the relative bank size and the ROAA for banks; that is, the coefficient is always positive but never statistically significant. Size is closely related to the capital adequacy of a bank since relatively large banks tend to raise less expensive capital and, hence, appear more profitable.

\subsection{Capitalization}

Pasiouras and Kosmidou (2007) and García-Herrero et al. (2009) indicated that the best-performing banks are those that maintain a high level of equity relative to their assets. The authors explained this relation with the observation that banks with higher capital ratios tend to face lower costs of funding due to lower prospective bankruptcy costs. For a bank with capital below its equilibrium ratio, the expected bankruptcy costs are relatively high, and an increase in the capital ratios raises the expected profits by lowering the interest expenses on uninsured debt. Empirical studies observing this positive relationship between capital and profitability are abundant, including those by Alexiou and Sofoklis (2009), Angbazo (1997) and Athanasoglou et al. (2008). Therefore, one expects banks with higher capital-to-asset ratios to be relatively safer and less risky than institutions with lower capital ratios. In line with the conventional risk-return hypothesis, we expect banks with lower capital ratios to have higher returns in comparison with better-capitalized banks.

\subsection{Cost-Income Ratio}

The cost-to-income ratio, a proxy for operational efficiency, has been declining almost everywhere to different degrees (Albertazzi \& Gambacorta, 2009), meaning that banks have lower expenses for a given level of output. Previous studies have suggested a positive and highly significant effect of efficiency on profitability (for example, Alexiou \& Sofoklis, 2009; Athanasoglou et al., 2008). This association denotes that the operational efficiency of a bank is a prerequisite for improving its profitability, implying that managerial ability in controlling costs (the so-called X-efficiency) is much more important than economies of scale. For instance, Abreu and Mendes (2002), in their study of several European countries, concluded that operating costs have a negative effect on profit measures despite their positive effect on net interest margins. The inclusion of bank expenses in profitability was also supported by Bourke (1989) and Molyneux and Thornton (1992), who found a link between bank profitability and expense management.

\subsection{Asset Quality}

The need for risk management in the banking sector is inherent in the nature of the banking business. Poor asset quality and low levels of liquidity are the two major causes of bank failures. During periods of increased uncertainty, financial institutions may decide to diversify their portfolios and/or raise their liquid holdings in order to reduce their risk. Abreu and Mendes (2002), who examined banks in Portugal, Spain, France and Germany, noted that the loans-to-assets ratio, as a proxy for risk, has a positive impact on the bank's profitability. Bourke (1989) and Molyneux and Thornton (1992), among others, concluded that there is a negative and significant association between the level of risk and the profitability. This result might indicate the fact that banks that are exposed to high-risk loans also have a higher accumulation of unpaid loans. These loan losses lower the returns of the affected banks.

\subsection{Revenue Diversification}

The decline in interest margins during the last decade has changed the traditional role of banks and forced them to diversify their sources of revenue. In this context, Elsas et al. (2010) noted that, initially, commercial banks typically increase their diversification by moving into fee-based businesses. Then they expand their business into trading activities or underwriting insurance contracts. Elsas et al. (2010) concluded that revenue diversification enhances bank profitability via higher margins from non-interest businesses. Stiroh and Rumble (2006) examined US financial holding companies (FHCs) from 1997 to 2002 to determine whether the observed shift 
toward activities that generate fees, trading revenue and other non-interest income improves performance. They concluded that diversification benefits exist between FHCs, but these gains are offset by the increased exposure to non-interest activities, which are much more volatile but not necessarily more profitable than interest-generating activities. Therefore, greater diversification of the banking business does not necessarily translate into an improvement in the bank's profitability; it may, in fact, be detrimental to profitability.

\subsection{Macroeconomic Factors}

The common variables include the inflation rate, the long-term interest rate and the rate of economic growth (Panayiotis et al., 2006). More recently, a number of studies have emphasized the relationship between a country's macroeconomic variables and its bank risk. For example, Allen and Saunders (2004) provided evidence of the importance of macroeconomic factors in determining the profitability of banks in the sample. Gelos (2006) examined the determinants of bank interest margins from 85 countries, including 14 from Latin America, using bank-and country-level data. The results showed that the spreads are large because of relatively high interest rates (which in the study is a proxy for high macroeconomic risk, including from inflation), less efficient banks and higher reserve requirements.

Revell (1979) introduced the issue of the relationship between bank profitability and inflation, noting that the effect of inflation on bank profitability depends on whether bank wages and other operating expenses increase at a faster rate than inflation. The question is how mature an economy is, so that future inflation is accurately forecasted to enable banks to manage their operating costs. Perry (1992) observed that the extent to which inflation affects bank profitability depends on whether the inflation expectations are fully anticipated. More recently, Yong and Floros (2012) examined the effects of inflation on bank profitability, while controlling for comprehensive bank-specific and industry-specific variables. The positive relationship found between inflation and profitability in the Chinese banking sector reflects the fact that the inflation in China can be fully anticipated and the interest rates adjusted accordingly. This further implies that revenues increase faster than costs.

Bikker and $\mathrm{Hu}$ (2002) identified possible cyclical movements in bank profitability. They established that bank profits are positively correlated with movements in the business cycle. Likewise, Afanasieff et al. (2002) made use of panel data techniques to uncover the main determinants of bank performance in Brazil and found that macroeconomic variables such as the GDP growth rate and inflation expectations are important in determining bank profitability over time.

Therefore, the empirical review for this research gives information on bank profitability. There is ample evidence of comprehensive accounts of developed countries and a few of developing ones, but fewer of SSA, signifying the requirement for further research on the sub-region. The empirical findings provide support that bank profitability is influenced by internal, sector-specific as well as macroeconomic factors.

\section{Variable of Interest}

\subsection{Dependent Variable}

The two commonly used dependent variables to measure profitability are return on assets (ROA) and return on equity (ROE). ROA is perhaps the single most important ratio for comparing the efficiency and the operational performance of banks. This ratio considers the returns generated from the assets that the bank finances; it is primarily an indicator of managerial efficiency. However, because it may be misleading due to off-balance-sheet activities, we use ROE, which is a measure of the return on shareholder funds.

\subsection{Independent Variables}

We divide the independent factors into two groups: the bank-specific factors and the external (industry and macroeconomic) factors. Among the bank-specific factors are the asset structure, asset quality, bank capitalization, cost-income ratio, size and revenue diversification.

To analyse whether the asset structure of the bank impacts on its profitability, we use the loans-to-total-assets ratio. This ratio indicates the percentage of the total assets of the bank that is tied up in loans; a higher value of this ratio indicates that the bank is less liquid. To measure the asset quality, we choose to examine the ratio of non-performing loans to gross loans. An increase in this ratio would indicate a worsening in the quality of the loan assets; that is, higher ratios correspond to lower asset quality. We use the proportion of the bank's own funds of the total assets (equity-to-total-assets ratio) to assess whether the level of capitalization is a determining factor of bank profitability; one would expect high values of this ratio to be coupled with larger returns for the bank.

To assess whether efficient banks are more profitable, we use as a proxy the cost-to-income ratio (CIR); this ratio measures the bank's overhead or running costs as a percentage of the income generated before provisions. 
However, because the effect of size on bank profitability seems to be non-linear, we use the logarithm of bank assets to accommodate this non-linear relationship. Finally, we measure the effect of revenue diversification using the Herfindahl-Hirschman index (HHI) calculated as follows:

$$
\text { HHIRD }=1-\left[\left(\frac{I N T}{T O R}\right)^{2}+\left(\frac{C O M}{T O R}\right)^{2}+\left(\frac{T R A D}{T O R}\right)^{2}+\left(\frac{O T H}{T O R}\right)^{2}\right]
$$

where INT denotes gross interest income, COM denotes gross commission and fee revenue, TRAD denotes trading revenue and OTH denotes all other gross operating income. TOR denotes the total operating revenue, which is basically the sum of the absolute values of INT, COM, TRAD and OTH.

From the literature, one would expect the relationship between economic growth and profitability to be positive, and the use of the annual growth rate of the real gross domestic product (GDP) explores this association. We measure the effect of inflation on bank profitability through the consumer price index (CPI) annual inflation rate. In addition, we use World Bank data statistics to obtain the average lending interest rate for each country in our sample.

\section{Econometric Modelling}

We construct a model that is capable of capturing the effects of bank-specific, industry-specific and country-specific macroeconomic variables on profitability in SSA. In the past, bank profits have shown a tendency to persist over time, reflecting impediments to market competition, informational opacity and/or sensitivity to regional/macroeconomic shocks to the extent that these are serially correlated (Berger et al., 2000). In order to test the relationship between the bank profitability and the bank-specific, industry-related and macroeconomic determinants described above, we estimate a linear regression model, which takes the form:

$$
\text { prof }=\alpha+\sum_{j=1}^{j} \beta X_{i t s}^{j}+\sum_{t=1}^{L} \beta X_{t s}^{t}+\sum_{m=1}^{M} \beta X_{t s}^{M}+\varepsilon_{i t s}
$$

where $\varepsilon_{i t s}=v_{i}+\mu_{i t s}$

In addition, $\sum_{j=1}^{j} \beta X_{i t s}^{j} i$ is a vector of bank-specific variables like the cost-income ratio. $\sum_{t=1}^{L} \beta X_{t s}^{t}$ is the vector of the banking industry; for instance, industry concentration, and $\sum_{m=1}^{M} \beta X_{t s}^{M}$ is the country's macroeconomic variables vector.

In order to evaluate the stationarity of the variables in the model, a unit root test was used, which is applicable to balanced panel data (Fisher-type tests based on augmented Dickey-Fuller). Stationarity means that the mean, variance and autocorrelation of a variable do not change with time. The results indicate that all the variables are stationary. Likewise, using recursive regression to test for structural stability, as shown below, there is no strong evidence to suggest a structural break.

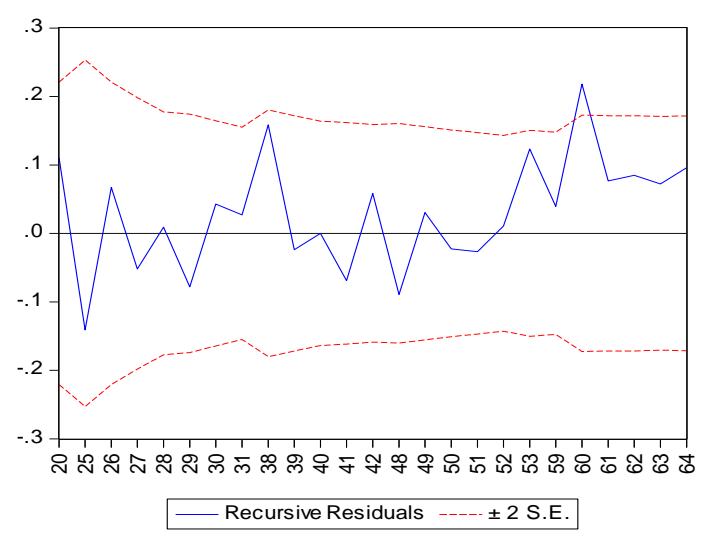

Figure 2. Test for a structural break 
There is also a need to recognize the differences in performance between the largest banks in the industry and the smallest banks across African banking. Therefore, in this research, only large banks by size are included. Thus, the 10 smallest banks in each country are excluded from the sample, leaving a balanced panel of 97 banks. As in other similar studies, we use unconsolidated financial statements from Bankscope; this choice prevents relevant differences in profit and loss statements and balance sheets of headquarters and subsidiaries from negating each other (García-Herrero et al., 2009).

Assessing the drivers of bank profitability could be affected by the potential for an endogenous character of certain variables. For instance, the more profitable a bank is, the more likely it is to increase its equity capital. This problem of causality could even move in the opposite direction; for example, higher bank profitability could lead to more employees and less efficiency (García-Herrero et al., 2009). In addition, some characteristics of banks that affect their profitability are difficult to measure or identify in an equation (the so-called unobserved heterogeneity); if the influence of such characteristics is not taken into account, there could be correlations between some of the coefficients of the explanatory variables and the error terms that bias these coefficients. That is:

$$
\mathrm{E}\left(\mu_{i} / X_{i}\right) \neq 0
$$

We estimate the model using pooled OLS, fixed (FE) and random (RE) effects after testing for heteroskedasticity and serial correlation using the Breusch Pagan with White test procedure as a possible remedy. The Akaike information criterion for FE is smaller than that for the pooled OLS. Therefore, the FE is a better estimator than the pooled OLS, indicating that there are fixed differences between banks across Africa. Using the Hausman test between the FE and the RE, the result indicates that FE is more appropriate, implying that the differences between the banks do not vary greatly from period to period. However, the results from the three estimation methods are reported for meaningful comparison. We also test whether our regression is correctly specified. As shown below using the Ramsey regression equation specification error test (RESET) test, the F-statistic takes the form of:

$$
\begin{aligned}
F_{(M ; N-k-1)} & =\frac{\left(S S R_{\hat{Y}}-S S R_{\hat{Y}^{2}}\right) / M}{S S R_{\hat{Y}^{2}} /(N-K)} \\
& =\frac{\left(S S R_{R}-S S R_{U R}\right) / M}{S S R_{U R} /(N-K)}
\end{aligned}
$$

where SSRs are the sum of squared residuals for the respective regressions; $\mathrm{SSR}_{\mathrm{R}}$ is the sum of squared residuals of restricted regression; and $\mathrm{SSR}_{\mathrm{UR}}$ is the sum of squared residuals of unrestricted regression. $\mathrm{M}$ is the number of restrictions; $\mathrm{N}$ is the number of observations; and $\mathrm{K}$ is the number of parameters estimated in the unrestricted equation. The $\mathrm{F}$ test is compared with the $\mathrm{p}$ value; our regression is correctly specified and we have not included irrelevant variables. The inclusion of an irrelevant variable may result in correlation with other variables, which could cause multicollinearity.

Table 1. Ramsey RESET test

\begin{tabular}{llcl}
\hline F-statistic & 0.359443 & Prob. F(1,24) & 0.5544 \\
Log likelihood ratio & 0.520301 & Prob. chi-square(1) & 0.4707 \\
\hline
\end{tabular}

\section{Empirical Result}

Table 2. Descriptive statistics

\begin{tabular}{lcccc}
\hline Name & Mean & Standard deviation & Minimum & Maximum \\
\hline Return on equity & 0.40 & 0.16 & 0.35 & 0.79 \\
Asset quality & 0.52 & 0.12 & 0.07 & 0.65 \\
Capitalization & 0.13 & 0.04 & 0.07 & 0.28 \\
Bank size & 4.8 & 0.26 & 4.2 & 5.29 \\
Revenue diversification & 0.21 & 0.10 & 0.07 & 0.39 \\
Cost-income ratio & 0.55 & 0.08 & 0.41 & 0.75 \\
Asset structure & 0.52 & 0.12 & 0.07 & 0.72 \\
Growth in GDP & 0.04 & 0.02 & 0.07 & 0.02 \\
Inflation rate & 0.12 & 0.07 & 0.04 & 0.26 \\
Loan Interest rates & 0.14 & 0.01 & 0.12 & 0.15 \\
\hline
\end{tabular}


Table 2 presents the descriptive statistics of the variables utilized in this study. The results show that the average return on equity is $40 \%$. This compares favourably with banks in South Asian countries, in which Perera et al. (2012) found that the mean ROA was $1 \%$, while the ROA for Turkish commercial banks was found to be $14 \%$ by Alper and Anbar (2011) and for Spain it was 14\% (Antonio, 2013). Likewise, as shown in Appendix 1, the ROE in SSA is much higher than that in other parts of the world. Looking at the minimum, mean and maximum values, generally, the statistics indicate a wide variation in both the bank-specific and the macro determinants of profitability of banks across SSA. Although banks in SSA are more profitable than those in Europe and other developed regional groups, the private credit to GDP in Africa is much lower, as shown in Appendix 2. This could be attributed to the fact that a huge percentage of the market share is controlled by foreign banks, as depicted by more foreign banks in SSA than in other regions, like South Asia, as shown in Appendix 4.

In addition, Table 2 shows that banks across Africa are well capitalized compared with those in Europe and America; that is, the average capitalization measured as equity to total capital is $13 \%$, while Gropp and Heider (2009) found that the banks in Europe were 90\% leveraged and those in America up to 99\%. This is perhaps one of the reasons why the banks in Africa were not as severely affected by the 2008 global financial crisis as their European and American counterparts.

Table 3. Pearson correlation matrix

\begin{tabular}{|c|c|c|c|c|c|c|c|c|c|c|}
\hline & ROE & CIR & AS & $\mathbf{A Q}$ & CAPZ & SIZE & RD & RGDP & INFL & LINTR \\
\hline ROE & 1 & & & & & & & & & \\
\hline CIR & -0.564 & 1 & & & & & & & & \\
\hline $\mathbf{A S}$ & 0.267 & -0.341 & 1 & & & & & & & \\
\hline $\mathbf{A Q}$ & 0.189 & 0.049 & -0.373 & 1 & & & & & & \\
\hline CAPZ & 0.165 & 0.275 & -0.035 & 0.053 & 1 & & & & & \\
\hline SIZE & 0.309 & -0.030 & -0.071 & 0.300 & 0.256 & 1 & & & & \\
\hline RD & 0.602 & -0.284 & 0.174 & 0.358 & 0.495 & 0.538 & 1 & & & \\
\hline RGDP & -0.032 & 0.009 & 0.054 & -0.001 & -0.111 & -0.176 & -0.007 & 1 & & \\
\hline INFL & 0.084 & -0.076 & 0.127 & -0.168 & -0.011 & -0.188 & -0.009 & -0.624 & 1 & \\
\hline LINTR & 0.103 & 0.013 & -0.094 & 0.072 & 0.186 & 0.570 & -0.008 & -0.365 & -0.287 & 1 \\
\hline
\end{tabular}

The dependent variable is ROE (return on equity). The independent variables are: CIR (cost-income ratio), AS (asset structure), AQ (asset quality), CAPZ (capitalization of the bank), SIZE (size of the bank), RD (revenue diversification), RGDP (real gross domestic product growth), INFL (inflation rate) and LINTR (loan interest rates).

Table 3 shows the results of the correlation between the dependent variable and the independent variables. The table shows a positive association between the capitalization and the profitability of the company. Likewise, the relationship between the size of the bank and its profitability is positive. Overall, the correlation relationships between the variables in the range below 0.8 would indicate that multicollinearity was not an issue in these estimations, as no two variables were highly correlated.

We conducted stepwise regression of our variables and the results indicate stable coefficients. In addition, the Wald test indicates a fine goodness of fit and the Hansen test shows no evidence of over-identifying restrictions.

Table 4. Stepwise regression results

\begin{tabular}{llll}
\hline Variable & Pooled OLS & Fixed effect & Random effect \\
\hline C & $0.9961^{* * *}$ & $18.1797 * * *$ & 1.02103 \\
& $(0.1554)$ & $(2.7072)$ & $(0.6376)$ \\
CIR & $-0.4839^{* * *}$ & $-0.6896 * * *$ & $-0.4867 *$ \\
& $(0.0663)$ & $(0.1748)$ & $(0.2482)$ \\
AS & 0.0400 & 0.0872 & 0.0473 \\
& $(0.0384)$ & $(0.0843)$ & $(0.1344)$ \\
AQ & $-0.1607 * *$ & $-0.0650^{*}$ & $-0.1467 * *$ \\
& $(0.0510)$ & $(0.1261)$ & $(0.0232)$ \\
CAPZ & $-0.7984 * * *$ & $-2.3137 * * *$ & $-0.7932 *$ \\
& $(0.1499)$ & $(0.5527)$ & $(0.6272)$ \\
\hline
\end{tabular}




\begin{tabular}{llll}
\hline SIZE & $0.0937 * * *$ & $0.1697 * *$ & $0.0990^{*}$ \\
& $(0.0275)$ & $(0.0779)$ & $(0.0963)$ \\
RD & $1.4882^{* * *}$ & $0.4803^{* *}$ & $1.4910^{* * *}$ \\
& $(0.0848)$ & $(0.2650)$ & $(0.3387)$ \\
RGDP & $0.7246^{* *}$ & $20.0707^{* * *}$ & 0.9096 \\
& $(0.3915)$ & $(3.0433)$ & $(0.5936)$ \\
INFL & -0.0570 & $-4.2679^{* *}$ & -0.0339 \\
& $(0.1081)$ & $(0.7561)$ & $(0.4519)$ \\
LINTR & 0.0328 & $115.6511^{* * *}$ & 0.0557 \\
& $(1.1465)$ & $(18.5420)$ & $(4.4231)$ \\
R squared & 0.80 & 0.92 & 0.80 \\
F-statistic & $150.74 * * *$ & $24.7730^{* * *}$ & $11.36 * * *$ \\
DW & 1.95 & 2.10 & 1.96 \\
AIC & -2.3527 & -2.9673 & $/$ \\
\hline Hausman test & & & Chi sq. 2.131 \\
& & Prob. 0.004 \\
\hline
\end{tabular}

$* * *, * *$ and $*$ denote significance at the $1 \%, 5 \%$ and $10 \%$ level, respectively. The value of D.W. (the Durbin-Watson statistic) is between $0<$ D.W. $<4$, thus indicating no autocorrelation. The Akaike information criterion (AIC) value for the fixed effect is less than that of pooled OLS and hence indicates that there are fixed differences between banks across SSA. Using the p-value, the Hausman test indicates that the fixed effect is a more efficient estimate than the random effect. The dependent variable is ROE (return on equity). The independent variables are: CIR (cost-income ratio), AS (asset structure), AQ (asset quality), CAPZ (capitalization of the bank), SIZE (size of the bank), RD (revenue diversification), RGDP (real gross domestic product growth), INFL (inflation rate) and LINTR (loan interest rates).

The coefficient of the cost-to-income ratio, our operational efficiency measure, is negative across the three estimation methods and highly significant with FE. This implies that the more efficient the bank is, the more profitable it is. This result is in line with Athanasoglou et al. (2008). It is also a testimony that banks have the ability to pass the overhead expenses on to customers through increasing the lending rate and decreasing the deposit rate. Put into perspective, the overhead-to-total-assets ratio is much higher in SSA than in Europe and Latin America, as shown in Appendix 3. Although not significant, the asset structure measured as the non-profit assets/total assets ratio has a positive influence on the return on average equity, which probably means that the bank can manage to transfer the cost of non-profit assets to its clients. Bank asset quality is one of the main issues for banking research. Statistically, bank asset quality is an indicator of the liquidation of banks (Demirguc-Kunt, 1989; Whalen, 1991). Our findings show a negative association between asset quality and profitability. That is, the more non-performing loans to total loans a bank has, the less profitable it is.

The income from non-interest income activities (HHIRD) significantly influences the profitability of the banks positively. This demonstrates that the banks in Africa are steadily shifting away from traditional sources of revenue, like loan-making, toward non-traditional activities that generate fee income, service charges, trading revenue and other types of non-interest income.

The capital ratio has a significant negative impact on bank profitability. This is in line with Goddard et al.'s (2010) exploration of a negative relationship between capital ratio and profitability for eight European Union member countries between 1992 and 2007. The negative coefficient could be because banks are required to retain a certain amount that is not lent out and hence is tied capital. However, banks with high capital-asset ratios are considered relatively safer in the event of loss or liquidation. On the other hand, low-capitalized banks may be considered risky. The result shows a positive effect of inefficiency on risk-taking, which supports the moral hazard hypothesis that poor performers are more vulnerable to risk-taking than high-performance banks.

All the estimated equations show that the effect of bank size on profitability is very important. This could be attributed to the likelihood that large banks are not only able to diversify their business portfolio but also to employ sophisticated techniques and enjoy the benefits of economies of scale. Moreover, larger banks can achieve greater product and loan diversification and so lower their risk profiles. Hence, the required rate of return becomes lower, which reduces their costs, generating higher profits. Similarly, large banks may be able to exert greater market power through a stronger brand image or implicit regulatory (too-big-to-fail) protection. Abnormal profits obtained through operating in wholesale or capital markets may also contribute to a positive size-profitability relationship.

The business cycle significantly affects bank profits, even after controlling for the effect of other determinants, 
which have a strong correlation with the cycle (e.g. provisions for loan losses). We further test for asymmetry in the effect of the business cycle across SSA, distinguishing between periods in which the output is above its trend value and those in which it is below. We find that the coefficient of cyclical output almost doubles when the output exceeds its trend value. In contrast, when the output is below its trend, the coefficient of cyclical output is insignificant. This result supports the view that banks are able to insulate their performance during periods of downswings.

Finally, expected inflation, as proxied by the previous period's actual inflation, negatively and significantly affects profitability. This could imply that banks' management is unable to forecast future inflation satisfactorily, which affects interest rates. This is because the result shows that the higher the lending rates, the more profitable the bank is.

\section{Conclusion}

The study was conducted to investigate the influence of bank-specific factors and macroeconomic variables on profitability, using a sample of 97 commercial banks from SSA countries from 2000 to 2012. A dynamic specification with a lagged profitability variable was employed to estimate the model. A dynamic balanced panel data model was employed to enable understanding of the dynamic relationship between the performances of variables and how they impact on the persistence of the dependent variable. Using the $\mathrm{F}$ test and Akaike information criterion, the fixed effects model was found to be the best estimator. However, we also estimated using random effects and pooled OLS in order to make a meaningful comparison.

Overall, the findings show that commercial banks in SSA are more profitable, with a mean return on assets of $40 \%$, than those in Asia, Europe or America. The result also provides evidence that the profitability of SSA commercial banks is influenced by bank-specific factors that have a direct relationship with bank management. This includes the efficiency of the management in terms of the cost-income ratio, the size of the bank, revenue diversification and capitalization. Furthermore, the result of this investigation shows that put into perspective, although the banks in SSA are more profitable than those in other regions, the private credit to GDP is much lower. This could be attributed to the fact that a huge percentage of the market share is controlled by foreign banks, which repatriate their profit to their home countries. In addition, macroeconomic factors like the growth of the economy, inflation and interest impact on the performance of the bank.

This study has a number of policy implications. For example, governments and other regulatory bodies should be aware of the factors that impact on the profitability of banks as these influence the private credit to GDP. For instance, the result shows that there is an inverse relationship between the capitalization and the profitability of banks. Over recent years, there have been regulatory reforms across the world, requiring banks to increase their capital. This has had an impact not only on the profitability of the banks but also on the private credit to GDP.

\section{References}

Abreu, M., \& Mendes, V. (2002). Commercial Bank Interest Margins and Profitability: Evidence from E.U. Countries. Working Paper Series, Porto.

Afanasieff, T., Lhacer, P., \& Nakane, M. (2002). The Determinants of Bank Interest Spreads in Brazil. Banco Central di Brazil Working Papers.

Albertazzi, U., \& Gambacorta, L. (2009). Bank profitability and the business cycle. Journal of Financial Stability, 5, 393-409. http://dx.doi.org/10.1016/j.jfs.2008.10.002

Alexiou, C., \& Sofoklis, V. (2009). Determinants of bank profitability: Evidence from the Greek banking sector. Economic Annals, 182, 93-118. http://dx.doi.org/10.2298/EKA0982093A

Allen, L., \& Saunders, A. (2004). Incorporating systemic influences into risk measurements: A survey of the literature. Journal of Financial Services Research, 26, 161-191. http://dx.doi.org/10.1023/B:FINA.0000037545.38154.8a

Alper, D., \& Anbar, A. (2011). Bank specific and macroeconomic determinants of commercial bank profitability: Empirical evidence from Turkey. Business and Economics Research Journal, 2(2), 139-152.

Angbazo, L. (1997). Commercial bank net interest margins, default risk, interest-rate risk, and off-balance sheet banking. Journal of Banking and Finance, 21, 55-87. http://dx.doi.org/10.1016/S0378-4266(96)00025-8

Antonio, T. (2013). What determines bank profitability? Evidence from Spain. Journal of Accounting and Finance, 53(2), 561-586. http://dx.doi.org/10.1111/j.1467-629X.2011.00466.x

Athanasoglou, P., Brissimis, S. N., \& Delis, M. D. (2008). Bank-specific, industry-specific and macroeconomic 
determinants of bank profitability. Journal of International Financial Markets, Institutions and Money, 18, 121-136. http://dx.doi.org/10.1016/j.intfin.2006.07.001

Berger, A. (1995). The profit-structure relationship in banking: Tests of market-power and efficient-structure hypotheses. Journal of Money, Credit and Banking, 27, 404-431. http://dx.doi.org/10.2307/2077876

Berger, A. N., Hanweck, G. A., \& Humphrey, D. B. (1987). Competitive viability in banking: Scale, scope and product $\mathrm{mix}$ economies. Journal of Monetary Economics, 20, 501-520. http://dx.doi.org/10.1016/0304-3932(87)90039-0

Berger, A., DeYoung, R., Genay, H., \& Udell, F. (2000). Globalization of financial institutions: Evidence from cross-border banking performance. Brookings Papers on Economic Activity, 2, 23-158.

Bikker, J. A., \& Hu, H. (2002). Cyclical patterns in profits, provisioning and lending of banks and procyclicality of the new Basel capital requirements. BNL Quarterly Review, 221, 143-175.

Bourke, P. (1989). Concentration and other determinants of bank profitability in Europe, North America and Australia. Journal of Banking and Finance, 13(1), 65-79. http://dx.doi.org/10.1016/0378-4266(89)90020-4

Chirwa, E. W. (2003). Determinants of commercial banks' profitability in Malawi: A cointegration approach. Applied Financial Economics, 13(8), 565-577. http://dx.doi.org/10.1080/0960310022000020933

Demirguc-Kunt, A. (1989). Deposit-institution failures: A review of the empirical literature. Federal Reserve Bank of Cleveland, Economic Review, Quarter 4.

Elsas, R., Hackethal, A., \& Holzhäuser, M. (2010). The anatomy of bank diversification. Journal of Banking and Finance, 34, 1274-1287. http://dx.doi.org/10.1016/j.jbankfin.2009.11.024

García-Herrero, A., Gavilá, S., \& Santabárbara, D. (2009). What explains the low profitability of Chinese banks? Journal of Banking and Finance, 33, 2080-2092. http://dx.doi.org/10.1016/j.jbankfin.2009.05.005

Gelos, G. (2006). Banking Spreads in Latin America. IMF Working Paper 06/44. http://dx.doi.org/10.5089/9781451863048.001

Goddard, J., Molyneux, P., \& Wilson, J. O. C. (2004). The profitability of European banks: A cross-sectional and dynamic panel analysis. The Manchester School, 72(3), 363-381. http://dx.doi.org/10.1111/j.1467-9957.2004.00397.x

Goddard, J., Molyneux, P., Liu, H., \& Wilson, J. O. S. (2010). The Persistence of Bank Profit. Bangor Business School Working Paper.

Gropp, R., \& Heider, F. (2009). The Determinants of Capital Structure. ECB Working Paper Series No. 1096/September 2009.

Micco, A., Panizza, U., \& Yanez, M. (2007). Bank ownership and performance. Does politics matter? Journal of Banking and Finance, 31(1), 219-241. http://dx.doi.org/10.1016/j.jbankfin.2006.02.007

Molyneux, P., \& Thornton, J. (1992). Determinants of European bank profitability: A note. Journal of Banking and Finance, 16, 1173-1178. http://dx.doi.org/10.1016/0378-4266(92)90065-8

Nissanke, M., \& Aryeetey, E. (1998). Institutional Analysis of Financial Market Fragmentation in Sub-Saharan Africa: A Risk Configuration Approach. Research Paper, No. 2006/87.

Panayiotis, P., Anthanasoglou, S., Brissimis, N., \& Mathaios, D. D. (2006). Bank Specific, Industry-Specific and Macroeconomic Determinants of Bank Profitability. Bank of Greece Working Paper, 25.

Pasiouras, F., \& Kosmidou, K. (2007). Factors influencing the profitability of domestic and foreign commercial banks in the European Union. Research in International Business and Finance, 21, 222-237. http://dx.doi.org/10.1016/j.ribaf.2006.03.007

Perera, S., Michael, S., \& Nguyen, M. (2012). Market concentration and pricing behaviour of Sri Lankan banks. South Asian Journal of Global Business Research, 1(1), 63-78. http://dx.doi.org/10.1108/20454451211205950

Perry, P. (1992). Do banks gain or lose from inflation? Journal of Retail Banking, 14(2), 30.

Revell, J. (1979). Inflation and Financial Institutions. Financial Times, London.

Short, T. (1979). Monitoring the macroeconomic determinants of banking system stability. Journal of Banking and Finance, 17(2), 117-137.

Smirlock, M. (1985). Evidence on the (non) relationship between concentration and profitability in banking. 
Journal of Money, Credit, and Banking, 17, 69-83. http://dx.doi.org/10.2307/1992507

Stiroh, K. J., \& Rumble, A. (2006). The dark side of diversification: The case of US financial holding companies. Journal of Banking and Finance, 30, 2131-2161. http://dx.doi.org/10.1016/j.jbankfin.2005.04.030

Valentina, F., Calvin, M., \& Liliana, S. (2009). The Determinants of Commercial Bank Profitability in Sub-Saharan Africa. IMF Working Paper Series No. WP/09/15.

Whalen, G. (1991). A proportional hazards model of bank failure: An examination of its usefulness as an early warning tool. Federal Reserve Bank of Cleveland, Economic Review, Quarter 1.

World Bank $\quad$ Financial Database. $\quad$ (2013). Retrieved from http://econ.worldbank.org/WBSITE/EXTERNAL/EXTDEC/EXTGLOBALFINREPORT/0,,contentMDK:2 3269602 pagePK:64168182 piPK:64168060 theSitePK:8816097,00.html

Yong, T., \& Floros, C. (2012). Bank profitability and inflation: The case of China. Journal of Economic Studies, 39(6), 675-696. http://dx.doi.org/10.1108/01443581211274610

Note

Note 1. Recapitalization led to a reduction of banks in Nigeria from 52 to 22 .

\section{Appendix 1. ROE over regional grouping}

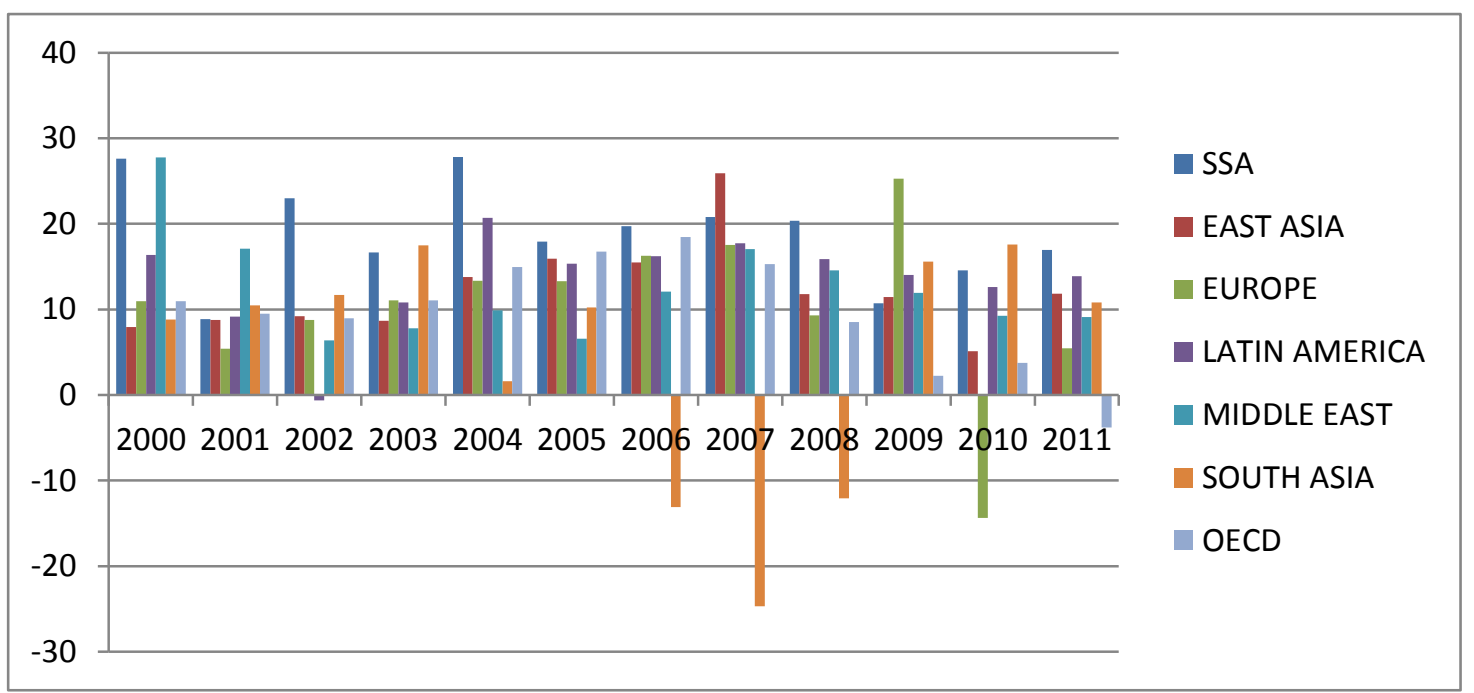

Source: Authors. Based on the data from the World Bank database.

\section{Appendix 2. Private credit to GDP}

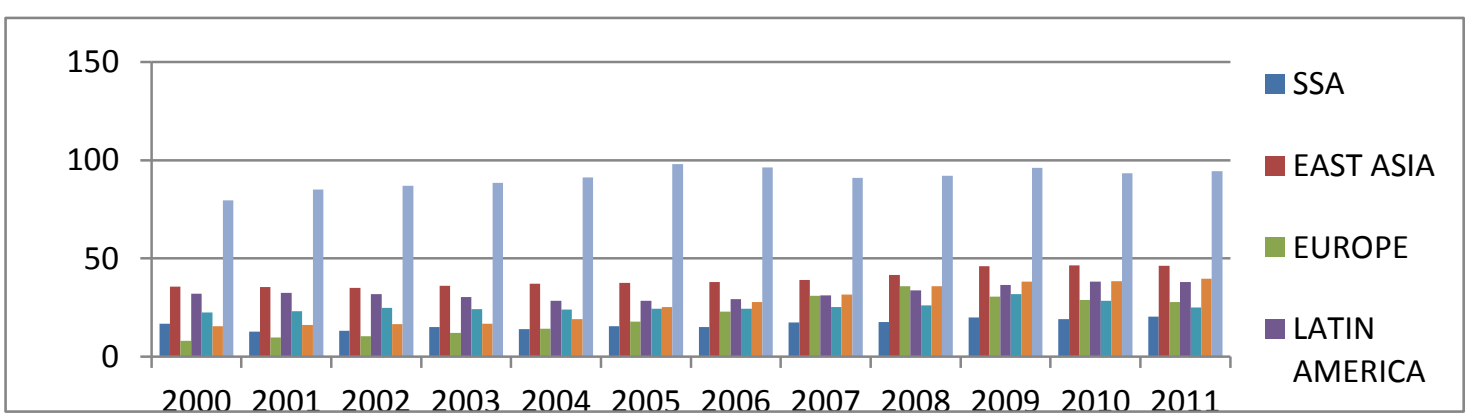

Source: Authors. Based on the data from the World Bank database. 


\section{Appendix 3. Overhead costs to total assets}

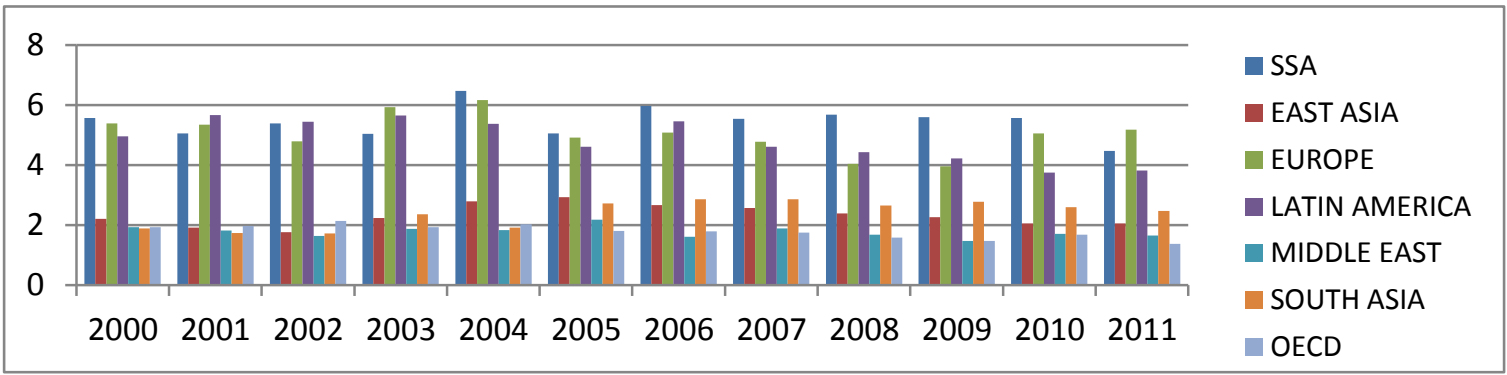

Source: Authors. Based on the data from the World Bank database.

Appendix 4. Number of banks across the regional groups

\begin{tabular}{|c|c|c|c|c|c|c|c|c|}
\hline & \multicolumn{2}{|c|}{1995} & \multicolumn{2}{|c|}{2000} & \multicolumn{2}{|c|}{2005} & \multicolumn{2}{|c|}{2009} \\
\hline & Number & Share & Number & Share & Number & Share & Number & Share \\
\hline \multicolumn{9}{|l|}{ All countries } \\
\hline Domestic & 3,120 & 0.80 & 2,993 & 0.74 & 2,805 & 0.70 & 2,576 & 0.66 \\
\hline Foreign & 774 & 0.20 & 1,058 & 0.26 & 1,175 & 0.30 & 1,334 & 0.34 \\
\hline Total & 3,894 & 1 & 4,051 & 1 & 3,980 & 1 & 3,910 & 1 \\
\hline \multicolumn{9}{|l|}{ Income groups } \\
\hline \multicolumn{9}{|l|}{$O E C D$} \\
\hline Domestic & 1,044 & 0.81 & 1,070 & 0.79 & 1,087 & 0.78 & 1,054 & 0.76 \\
\hline Foreign & 237 & 0.19 & 280 & 0.21 & 315 & 0.22 & 332 & 0.24 \\
\hline Total & 1,281 & 1 & 1,350 & 1 & 1,402 & 1 & 1,386 & 1 \\
\hline \multicolumn{9}{|l|}{ Otherhigh-income } \\
\hline Domestic & 73 & 0.70 & 67 & 0.66 & 61 & 0.59 & 63 & 0.59 \\
\hline Foreign & 32 & 0.30 & 34 & 0.34 & 42 & 0.41 & 44 & 0.41 \\
\hline Total & 105 & 1 & 101 & 1 & 103 & 1 & 107 & 1 \\
\hline \multicolumn{9}{|l|}{ Emerging markets } \\
\hline Domestic & 1,456 & 0.82 & 1,293 & 0.73 & 1,143 & 0.70 & 1,001 & 0.64 \\
\hline Foreign & 330 & 0.18 & 473 & 0.27 & 488 & 0.30 & 569 & 0.36 \\
\hline Total & 1,786 & 1 & 1,766 & 1 & 1,631 & 1 & 1,570 & 1 \\
\hline \multicolumn{9}{|l|}{ Developing countries } \\
\hline Domestic & 547 & 0.76 & 563 & 0.68 & 514 & 0.61 & 458 & 0.54 \\
\hline Foreign & 175 & 0.24 & 271 & 0.32 & 330 & 0.39 & 389 & 0.46 \\
\hline Total & 722 & 1 & 834 & 1 & 844 & 1 & 847 & 1 \\
\hline \multicolumn{9}{|l|}{ Region } \\
\hline \multicolumn{9}{|l|}{ East Asia and Pacific } \\
\hline Domestic & 254 & 0.82 & 272 & 0.81 & 289 & 0.81 & 282 & 0.75 \\
\hline Foreign & 57 & 0.18 & 64 & 0.19 & 69 & 0.19 & 95 & 0.25 \\
\hline Total & 311 & 1 & 336 & 1 & 358 & 1 & 377 & 1 \\
\hline \multicolumn{9}{|l|}{ Eastern Europe and Central Asia } \\
\hline Domestic & 664 & 0.85 & 602 & 0.72 & 500 & 0.61 & 418 & 0.53 \\
\hline Foreign & 114 & 0.15 & 234 & 0.28 & 317 & 0.39 & 371 & 0.47 \\
\hline Total & 778 & 1 & 836 & 1 & 817 & 1 & 789 & 1 \\
\hline \multicolumn{9}{|l|}{ Latin America and Caribbean } \\
\hline Domestic & 596 & 0.75 & 479 & 0.65 & 395 & 0.65 & 367 & 0.61 \\
\hline Foreign & 198 & 0.25 & 256 & 0.35 & 217 & 0.35 & 232 & 0.39 \\
\hline Total & 794 & 1 & 735 & 1 & 612 & 1 & 599 & 1 \\
\hline \multicolumn{9}{|l|}{ Middle East and North Africa } \\
\hline Domestic & 143 & 0.82 & 131 & 0.77 & 116 & 0.71 & 101 & 0.64 \\
\hline Foreign & 32 & 0.18 & 40 & 0.23 & 48 & 0.29 & 57 & 0.36 \\
\hline Total & 175 & 1 & 171 & 1 & 164 & 1 & 158 & 1 \\
\hline \multicolumn{9}{|l|}{ South Asia } \\
\hline Domestic & 133 & 0.93 & 143 & 0.91 & 148 & 0.91 & 139 & 0.86 \\
\hline Foreign & 10 & 0.07 & 15 & 0.09 & 15 & 0.09 & 22 & 0.14 \\
\hline Total & 143 & 1 & 158 & 1 & 163 & 1 & 161 & 1 \\
\hline \multicolumn{9}{|l|}{ Sub Saharan Africa } \\
\hline Domestic & 213 & 0.69 & 229 & 0.63 & 209 & 0.58 & 152 & 0.46 \\
\hline Foreign & 94 & 0.31 & 135 & 0.37 & 152 & 0.42 & 181 & 0.54 \\
\hline Total & 307 & 1 & 364 & 1 & 361 & 1 & 333 & 1 \\
\hline
\end{tabular}

\section{Copyrights}

Copyright for this article is retained by the author(s), with first publication rights granted to the journal.

This is an open-access article distributed under the terms and conditions of the Creative Commons Attribution license (http://creativecommons.org/licenses/by/3.0/). 